\title{
A CRITICAL ANALYSIS OF REPORTING ON THE TRC DISCOURSES IN DIE KERKBODE
}

\author{
Christine Anthonissen \\ Department of Linguistics \\ Stellenbosch University
}

\begin{abstract}
This article uses Critical Discourse Analysis as a methodological framework for considering the ways in which Die Kerkbode mediated the South African Truth and Reconciliation Commission (TRC) from 1995 to 2001. It reflects on the reasonable expectations one could have of a publication of the nature of Die Kerkbode, the official publication of the Dutch Reformed Church, with its very specific readership. It also reflects on how such expectations were met. The analysis indicates how an early position of doubt in the integrity of the TRC process gradually developed into one that responded sensitively to the volume of testimonies to human rights abuses of the years of struggle. However, it also indicates a primary interest in the image of the DRC and its own participation (or not) in the TRC processes. There is no coverage of particular narratives of the special event hearings, the Human Righrts Violations hearings or the Amnesty hearings. No reference is made to real events which were topicalised during the TRC hearings themselves. Eventually, in 2001 there appears to be a return to a position that questions the value of the TRC and is concerned more with amnesty for all than with restitution for those who suffered. This calls for further reflection on why the DRC could at the time not respond with more empathy and a more considered notion of reconciliation.
\end{abstract}

\section{Introduction}

This article takes an interest in the ways in which the official Dutch Reformed Church (DRC) responded to a political initiative aimed at securing peace and encouraging reconciliation between formerly violently opposed groups of the South African population. Since the 1960s it was clear to the National Partly led government that from the ranks of the disenfranchised in the country there was accelerated opposition which took on forms ranging from civil disobedience to armed resistance. In their attempts to secure and sustain their position, the government used the powers of the state to suppress such resistance; in fact, often the powers of state were abused when improper measures were taken with little consideration of internationally respected conventions on protecting the rights of all subjects. In justifying the use of excessive force, both State and Church, specifically the "Apartheidskerk" of the time, invoked the rhetoric of having a Christian duty to protect the country and its people from the threat of communism. When a negotiated settlement was achieved between the warring groups by 1994, the provision made for addressing the vast range of unresolved issues relating to injustice and human rights abuses of the years of conflict, made an appeal to the strong religious affiliations of the larger part of the South African community.

The Interim Constitution of 1993 allowed for a body that would consider how to meaningfully confront politically inspired violence of the recent past. Finally, the Promotion of National Unity and Reconciliation Act, No 35 of 1995, gave rise to the institution of an officially sanctioned Truth and Reconciliation Commission (TRC). The 
mandate of the TRC has been explained and elaborated in a great number of publications (cf. Krog: 1998, Verwoerd: 1999, Tutu: 2000, Boraine: 2000, Rotberg/Thompson: 2000, James/Van de Vijver: 2001). Here, to articulate what was intended by the process the TRC was to manage, I shall refer to just one set of phrases that occur repeatedly in the Interim Constitution of 1993, the Constitution of 1995, the TRC Act of 1995, the Explanatory Memorandum to the parliamentary Bill of 1995 and the amended TRC act of 1997:

The Commission was to provide "a historic bridge between the past of a deeply divided society characterized by strife, conflict, untold suffering and injustice, and a future founded on the recognition of human rights, democracy and peaceful co-existence for all South Africans, irrespective of colour, race, class, belief or sex." It was stated that "the pursuit of national unity, the well-being of all South African citizens and peace require reconciliation between the people of South Africa and the reconstruction of society." And it was made explicit that "there is a need for understanding but not for vengeance, a need for reparation but not for retaliation, a need for ubuntu but not for victimization" (from Codrington:1997).

This was the language of the institution of the political process aimed at national reconciliation. How did the DRC position itself in this particular discourse of bridging past and future, of pursuing unity and well-being? This article will investigate the language of the DRC as it took part in this discourse. Specifically, it will focus on the discourse in the official publication of the church, Die Kerkbode.

To start out I shall give the scope of this investigation. If one is interested in reconstructing from official documents the ways in which the DRC responded to the institution of the TRC and to its processes of research, the testimonies, hearings, decisions, announcements, outcomes, and so on, of this commission, then one could investigate many more documents than just the official publication of the church. One could consider checking a variety of other archived documents, such as agendas and minutes of meetings held at various levels of church leadership and decisionmaking, official statements, press releases and open letters. That does not fall within the scope of this article.

My commission here is to consider how Die Kerkbode reported on the TRC, what kinds of discourses it produced and what the functions of such reports were. ${ }^{1}$ Die Kerkbode is a unique kind of publication in that it is not a regular newspaper with a general commitment to reporting all current breaking news as the daily or weekly news media do. It is the official public voice of the Dutch Reformed Church that, as one of its functions, communicates the official position of the church on pertinent matters, to its members. It represents the membership and the leadership of the church, and as such it will reflect and affect the interests and perceptions of its constituency.

In an earlier discussion ${ }^{2}$ on trends in the reporting of Die Kerkbode, one of the participants expressed the opinion that one should not take the views expressed in this publication to be those of the church leadership, but rather as those of the editor. I do not agree with such a position. Die Kerkbode is officially recognised and supported by the church, the editor is elected and appointed by the church leadership and certainly works in consultation with other church officials. His executive position does not feed into sole responsibility for what is published and how.

1. Most of the research for this article was done in preparation of lectures and workshops while I was in Hamburg as guest lecturer on the SFB 520 program during December 2002 and January 2003. I would like hereby to give recognition to my hosts: without their support there would have been none of all this.

2. At a workshop on 20 December 2002 in Hamburg. 
This article will be structured as follows:

1. I shall very briefly indicate a number of recent trends in CDA, just to supplement information on this particular approach to discourse analysis.

2. I shall give a brief characterisation of Die Kerkbode as a form of media.

3. I shall consider how the TRC was topicalised in articles in Die Kerkbode. This I shall do by comparing how the TRC was dealt with in comparison to other front page topics.

4. I shall discuss a number of excerpts from the reports that I looked at, considering the position they express in relation to the TRC participants, hearings and findings.

\section{Theoretical framework}

The analysis here will be done from the perspective of "Discourse Sociolinguistics" (Wodak: 1996, Wodak/Meyer: 2001), which is one of the approaches taken in Critical Discourse Analysis (CDA). I shall not give a detailed discussion of what CDA is and how it is used in media discourse analysis, as the elaborate theoretical position has been introduced well in quite a number of publications (cf. Fairclough: 1989, Fowler: 1991, Titscher et al.: 1998, Reisigl/Wodak: 2001, Wodak/Meyer: 2001). Specifically, an outline of the CDA approach that indicates its use for analysing church media discourse has been given in a special edition of Scriptura, October 2001, which presents the proceedings of a previous symposium organised by the SFB $520 .{ }^{3}$ Nevertheless, to place my analysis theoretically, and to explain the way in which attention is directed at specific details of the TRC reports in Die Kerkbode, I shall mention a number of recent and salient developments in CDA studies.

Critical Discourse Analysis is distinguished from Discourse Analysis in that it takes an interest not only in structural aspects of coherent texts, but also in how power relations and ideological positions of participants in the discourse, are mediated. This particular interest in "language, power and ideology" links CDA to critical social theories that have their roots in the epistemology introduced by the Frankfurt School in the 1930s. Such an approach to linguistic analysis recognizes the situatedness of all discourse in that it pays attention to the role of context, including the historical context, in constructing the meanings of discourses. Typical of this approach is that it characterises language as a form of social action, and that much attention is given to the ways in which related discourses are intertextually connected. (cf. Kress \& Hodge: 1979, Fairclough: 1989, Fairclough: 1995b, Wodak: 1989, Wodak \& Meyer: 2001) An inventory of the kinds of discourses that have productively been analysed in the CDA framework, gives an impression of the interdisciplinary nature of such an approach. While considering the linguistic and textual structures of the given discourses, these analyses draw on historical, social, sociological, psychological, anthropological and philosophical insights as well. For example, CDA scholars have investigated discourses conducted in public institutions such as the media, governmental committees, hospitals, schools, and so on. Such discourses include:

- media coverage of public discourses during the Austrian presidential election campaign of 1986 (Wodak et al.: 1994),

- political discourses defending the introduction in Austria of strict visum requirements for immigrants from East block countries who were formerly accepted as asylum seekers (Matouschek et al.: 1995),

3. See Anthonissen, C. 2001. Critical discourse analysis: a methodological discussion for analysis of editorials on the state of emergency, Die Kerkbode 1986-1989. In Scriptura 76 (2001), pp.17-31. 
- discourses between medical officers and patients in a day hospital (Wodak, 1996),

- discourses on national identity in anticipation of the change of sovereignty in Hong Kong (Scollon: 1999),

- radio news broadcasts on the killing of two Greek-Cypriots during riots at the time of the $22^{\text {nd }}$ anniversary of Turkish occupation of Northern Cyprus (Chouliaraki: 1999),

- European Union decision making discourses on un/employment (Muntigl et al.: 2000),

- South African media discourses simultaneously publishing restricted information and protesting the restrictive measures during the states of emergency in the late 1980s (Anthonissen: 2002).

The ways in which printed and broadcast media have become powerful agents in shaping public perceptions have repeatedly been highlighted in CDA studies. (cf. Fowler: 1991, Fairclough: 1995a, Scollon: 1998) Identifying media discourse as a form of social action, Scollon (1998: 17-18, 75, 92) points out that media discourses have more resemblance to sport events or theatre productions than to face-to-face interactions between senders and receivers of messages. There is a community of news producers who produce a "spectacle-for-observation" in the form of a newspaper or television broadcast. The spectacle is played out among a set of performers (the "newsmakers"). Producers and receivers of news are rarely in close proximity to one another. The receivers have limited opportunity to interact with the sender(s) as there is no direct or immediate channel between these participants. The audience thus has limited opportunity to interrupt or to question any aspect of the message. Also, the mediated identities of the players, the newsmakers, are largely in the hands of the producers. This puts the producers of news discourses in relatively powerful positions in the mediation process. Indirectly, of course, the identities of the producers and receivers are also mediated. What is aspects of a news story are selected and how these are presented, says something about the sender. It also says something about the implied reader.

Much has been made of the common media practice of representing events and statements by selecting and rephrasing content in ways that reflect the writer and publisher's interests more than those of the newsmakers. Chouliaraki (1999: 39) emphasises this by attending to this practice as one principled on how it "brings together and reorganizes other discursive practices in a new order". This is eminently illustrated in the practice of a church publication that selects issues raised in the much more widely distributed public media such as daily newspapers, highlights those aspects that it deems to be of interest to its constituency, and represents the views and actions of public figures in a framework that the publication itself controls. The attention that Die Kerkbode gives to the TRC and prominent role players in this national initiative, is an instantiation of this very general media practice. To make this clear, this article will trace and interpret the general pattern of reporting on the TRC in Die Kerkbode over a period of 6 or 7 years.

\section{Die Kerkbode in the context of mass communication}

As has been indicated above, Die Kerkbode is a-typical as a publication that disseminates news. It is an institutional voice in that it officially represents the DRC leadership and is largely expected to communicate a message that the leadership would support and would want its constituency to receive. It does not use a set of independent journalists who are required to do investigative reporting or to collect breaking news. Also, it has a well 
identified target audience. This publication has a clear impression of its implied reader: it can confidently assume that the average reader is a member of the DRC who has an interest in what is happening in the church, has a special commitment to the church and expects to be informed of the position the official church takes regarding secular matters as well as matters of faith.

At an earlier stage in its history Die Kerkbode was published independently of other newspapers and circulated directly to subscribed members and congregations. More recently however, considering the cost of publishing and circulating to relatively small numbers of subscribers, Die Kerkbode became aligned to larger secular news agencies, and dependent on daily newspapers in the NASPERS group for being circulated to a community beyond the reach of congregational structures. This suggests that the DRC is generally comfortable being associated with the political position taken in NASPERS newspapers, such as Die Burger ${ }^{4}$ and Beeld. ${ }^{5}$ It is to be expected that the DRC's perspective on secular matters and its relation to political institutions would be broadly in line with the position of the media whose circulation mechanisms it relies on. Two to three editions per month are published. A large amount of the content of Die Kerkbode is given in the form of regular columns that carry information on church meetings, outreaches, celebrations or losses in local parishes, current controversies and the likes. Such columns also give guidance on topical, ethical matters, devotions, meditations on Scripture, and so on. The front page news items are selected according to criteria that consider the interest of the church and dedicated members. An overview of what was generally selected as front page news during the years that the TRC hearings and reports were taking place, to a large extent reflects the self-constructed identity of church and membership.

\section{The positioning of Die Kerkbode in its consideration of the TRC}

As it had done during the years of transition to a Government of National Unity, and eventually a multiparty, inclusive democracy, Die Kerkbode continued in the years after 1994 to refer to topical events that were elaborately covered in the regular newsmedia (i.e. in local newspapers, radio and television broadcasts). The following sections will reflect on what news items were selected as important topics for reflection in Die Kerkbode generally, on the kind of interest the publication took in events related to the TRC, and on the position the DRC took regarding the hearings, prominent participants, the information that was disclosed, the outcomes and the value of the TRC during the years from 1995 to 2002. There are three guiding questions in considering how and how much Die Kerkbode reported on the TRC. These are:

1) How much attention could a publication of the kind of Die Kerkbode, reasonably have been expected to give to an institution such as the TRC?

2) Which particular issues related to the broad TRC history were found to be pertinent to the interests of the publishers and readers of Die Kerkbode?

3) What attitude towards the TRC, its officials, its functions and its practices was communicated in the reports related to the TRC? Sections 4.1 and 4.2 will probe information that will assist in answering these questions.

4. Published in Cape Town and circulated in the Western Cape (though there are also regional editions in the Eastern Cape).

5. Published in Johannesburg and circulated in Gauteng and a number of the northern provinces of the country. 
4.1 Headlines, columns, pages: how die Kerkbode topicalised the TRC

The front page of Die Kerkbode is organised in a manner similar to secular newspapers in that it carries a current, topical news report. General themes addressed in front page articles from 1995 to 1999 give an impression of what was selected to be of primary interest to the DRC and its members. During the two years 1995 and 1996, when the TRC was instituted and public hearings started, much attention was given in Die Kerkbode to increased crime rates in the country and how this was found to affect the readership. While the new constitution was being drafted and discussed in parliament, moral and ethical issues that seemed to disregard the church's position, were often topicalised. These included discussions on

- crime and levels of violence (11 front page reports across 78 publications over 5 years),

- religious instruction in schools (10 front page reports across 78 publications over 5 years),

- religious meditation in the public media and the role of a Christian media in the public debate (13 front page reports across 78 publications over 5 years),

- abortion (7 front page reports across 78 publications over 5 years), and

- other moral issues such as the abolition of the death penalty, euthanasia, a state supported lottery, state support for NGO charities, acceptance of gay members in the church, corruption, doing sport on Sundays, satanism, cloning (in all (15 front page reports across 78 publications over 5 years).

The primary interest in moral issues, is reflected in that the list of issues mentioned above formed the topic of $72 \%$ (56 out of 78) of the front page articles published from 1995 to $1999 .{ }^{6}$ Also fairly topical at the time was the matter of church unity that considered relations between the various racially distinguished Dutch Reformed Churches (the DRC, DRC in Africa, DRC Mission Church, and Reformed Church), ${ }^{7}$ that is still a matter of much debate (21 front page reports across 78 publications over 5 years). During 1995 and 1996,5 out of 33 editions carried front page reports related to the institution and first hearings of the TRC. ${ }^{8}$ In selecting front page topics the main interest of Die Kerkbode as the official voice of the DRC is made evident. Certainly, the selection criteria according to which front page news was decided from 1995 to 1999 and beyond, did not prioritise the TRC. Nevertheless, considering the nature of the publication there was a fair amount of attention, even if the focus was fairly narrowly set on the status of the DRC and its views on the TRC process.

In all it was not only the front page reports that introduced reflection on the TRC. From time to time the leading articles were dedicated to consideration of TRC related matters, and occasionally columns such as "Vuurhoutjie" or "Forum" referred to this topic. Although the letter columns reflected some of the conflicting positions of readers, they never carried vigorous debate on the TRC. On the odd occasion the regular column with contributions of editors of other church publications, notably those of the Uniting Reformed Church, the Hervormde Kerk and the Gereformeerde Kerk also topicalised the public interest in the TRC. In the years from 1998 to 2002 when concerns about how amnesty

6. It is possible that 78 is not the full number of editions published (I may have missed one or two editions), but the figures certainly give a fair reflection of the matters that were topicalised and of their frequency.

7. This was of course before before the Uniting Reformed Church emerged in 199 ?.

8. Cf. the editions of Die Kerkbode, 26 May 1995, 6 October 1995, 9/10 February 1996, 1 March 1996, 18 October 1996 
would be dealt with and what kind of restoration would be offered to victims whose claims had been heard and properly recognised, and when the final report was due, Die Kerkbode directed considerably less attention to this topic than earlier on.

Although "reconciliation" is a central theme in Christianity, and as a concept it was under much public and scholarly scrutiny in the years following the advent of a new dispensation in South Africa, it was limitedly and superficially unpacked and debated in Die Kerkbode. ${ }^{9}$ Consideration of what precisely was in focus in the articles that did topicalise the TRC, is particularly informative. The following section will take a closer look.

\subsection{Closer readings: textual indicators of a shifting position}

Here I shall refer to the headlines that introduced TRC-related topics, and indicate what was brought into focus in the articles under each heading. I shall also show how the position of Die Kerkbode becomes clear in its reporting across the period 1996 to 2000, by considering excerpts that typify the style, tone and content of such reporting.

\subsubsection{Headlines as indicators of interest}

On 26 May 1995, when the planned TRC process was still underway, and before the TRC commissioners had been appointed, the concern of the DRC was articulated on the front page in the words "Wees onpartydig, vra NGK vir Waarheidspan" (Be impartial, DRC requests Truth Team). The front page report refers to a declaration issued by the Algemene Sinodale Kommissie (the "ASK", a body representing the DRC leadership countrywide) that stated the DRC sees itself as an important actor in the process of reconciliation in South Africa, and at the same time expressed concern that the process would not be impartial. It encourages its pastors to give support to the aggrieved as well as the accused who would be called to testify.

A similar expression of doubt that the process would be an evenhanded one, is evident in the front page headline of 6 October 1995: "Waarheidsolifantjie' sal fyn moet trap" (Truth-baby-elephant will have to tread carefully) Slightly derogatory reference is made to a metaphor introduced by the Minister of Justice, Mr Dullah Omar, when he compared the process of getting the TRC legislation and structures in place, to the long gestation period of elephants. The focus is not on the wrongs of the past that need to be put right, but specifically on the need for a "new morality" in a society where people are longing for an end to violence and crime. The church's intention to monitor the TRC process carefully is repeatedly stated. The only indication of how the "new morality" should differ from what went before, is given in a vague phrase: "Respect for life should be the password". The TRC investigation into massive abuse of power, largely of power derived from state mechanisms, where respect for the lives of countless, mostly black citizens was patently absent, is only secondarily implied. In referring to soaring crime rates, the primary implication is that the lives to be respected are those that have come under threat more recently, namely those of the communities to which Die Kerkbode's readership belong.

None of the DRC's nominations for inclusion in the list of Commissioners were successful. However, concern about Afrikaner and DRC support for the process eventually led to the inclusion of DRC theologian, Piet Meiring. The lead article of 9/10 February 1996 refers to this under the heading "Meiring 'n aanwins vir Waarheidskommissie"

9. Compare this for example with the way other church publications considered these concepts, as in Codrington: 1997. 
(Meiring an asset to the Truth Commission). It is clear that there is both relief and joy about this appointment: Prof Meiring is seen as an "ecumenical builder of bridges with an evangelical heart". This lead also refers to a letter it received from 46 DRC pastors who expressed their concern at the unduly sceptical stance of the DRC as it was articulated in the first Die Kerkbode reports on this topic. Although the lead supports the plea of the 46 for constructive participation, it reiterates the formerly expressed fear that the sins of apartheid will be over-emphasised while anti-apartheid sins will be trivialised. Under "Die kritiese afstand" (The critical distance) the lead of 1 March 1996 topicalises discussions the church leadership held with TRC chairperson, Archbishop Desmond Tutu. Readers are reassured that no witch hunt is intended, they are warned that the process may go on for quite a while, and that it may be traumatic. Nevertheless, it could bring healing. This marks a change in tone compared to the reports up to February 1996. Although there is still scepticism as to the possibility that "the truth" can be properly captured, and the church is urged to maintain critical distance, there is some recognition of other perspectives on recent history than just their own. Probably to appease a more conservative contingent in the church, positive reference is specifically made to Adv Chris de Jager of the Vryheidsfront ${ }^{10}$ who resigned from all political positions he held in order to be unrestrained in pursuing his responsibilities as a Truth Commissioner.

A lead article of 6 September 1996 asks "' $n$ NGK-voorlegging aan die WVK?" (A DRC presentation to the TRC?) Arguments for and against such a presentation are highlighted, and then Die Kerkbode makes it clear that its position is in favour of such a presentation. To motivate its position, the following is mentioned: the TRC cannot be wished away. By boycotting it one would be allowing a skewed perspective of the recent history to prevail. By taking a testimony to the TRC the church would be in a position not only to acknowledge mistakes it may have made, but also to highlight actions of the past decades that were good and acceptable. In particular reference is made to the DRC's confession of guilt that caused a considerable number of members to withdraw and find a confessional home elsewhere. ${ }^{11}$ The lead is concluded with a reminder that going to the TRC does not condone what is happening there. Rather, such a course of action would create an opportunity for public testimony. ${ }^{12}$ On 18 October 1996 under the headline "Ons het geswyg toe ons moes getuig - NGK-ring" (We were silent when we should have spoken out - DRC presbytery) the front page report topicalises the testimony the circle of Stellenbosch parishes brought to the TRC in the hearings held at Paarl on 15 October. The ASK had found the various regional synods divided on the question as to whether there should be an official delegation to the TRC, to the extent that it could not muster sufficient support to actually do so. This gives interesting significance to the special attention Die Kerkbode gave to the decision of a single presbytery, the Ring van Stellenbosch, to draft and present its testimony to the TRC. For fair balance (and tacitly recognizing the disagreement of a conservative contingent in the constituency) the protest of a number of DRC members of

10. The right-wing political party that advocates the development of a white homeland.

11. This follows a more general pattern of vague reference: the editor does not give specific information on when the church confessed guilt, what the circumstances were or to which denominations it lost members. He assumes that readers will have sufficient contextual knowledge to fill in the details from their own memory. Most probably the reference here is to an ecumenical meeting of the DRC family focussed on the thorny issueof church unity, at Rustenburg in 1990. At this occasion Prof Willie Jonker read a confession which acknowledged the DRC's role in the suffering caused by apartheid. Many who left the DRC at the time, joined the APK (Afrikaanse Protestantse Kerk).

12. The conclusion also follows a regular pattern: often the editorial is concluded with a remark that could be taken as a slightly pedantic expression of faith that states the moral high ground of the church. 
the Ring van Stellenbosch under leadership of a historian, Prof Pieter Kapp, against the particular testimony is also recorded.

By 1997 the processes of instituting the TRC and setting up public hearings had become a regular item in the news reporting landscape. Besides reporting on the events themselves, there had been public debates on issues such as the reliability of certain testimonies, the bias or not of certain commissioners, the status of allegations made in the course of hearings and submissions, and so on. Die Kerkbode did not give a regular update or systematic record of specific hearings and events. Quite a number of months would go by with minimal if any attention to the work of the three committees: the committee responsible for hearings and submissions related to Human Rights Violations, the Amnesty Hearings and the Reparation and Rehabilitation Committee. Towards the end of 1997 two lead articles were dedicated to the responses of the DRC to theTRC as an institution. The issue for the DRC remained "to testify or not to testify": should the DRC officially address the TRC or not? Using a regular confessional order of confessing guilt as a preamble to being granted forgiveness, the headline "Getuienis, skuld, belydenis, vergifnis" (Testimony, guilt, confession, forgiveness) on 7 November 1997 introduces a lead article that encourages DRC attendance of a special meeting arranged by the TRC for submissions by various churches. Four weeks later, in the edition of 5 December 1997, the second lead gives "Feite oor die NG Kerk en die WVK" (Facts about the DRC and the TRC). Answering to complaints of a lack of clarity, of being confused, and of disagreement within the church, an explanation is given of the status of the submissions by the Western and Southern Cape Synod, and of the moderator of the General Synod, Rev Freek Swanepoel. These were definitely not official, not made as representative of what the DRC generally would stand for.

In March 1998 an editorial titled "Tutu se woord" (Tutu's word (of honour)) relates a number of poignant matters that were raised in an interview Die Kerkbode had with (former) Archbishop Desmond Tutu as chairperson of the TRC. The tone here is patronizing, and expresses doubt as to whether Dr Tutu can be counted on to keep to his word. In November of the same year the front page and the lead article report on the handing over of the final TRC report to Pres Mandela. There is a return to the opening position Die Kerkbode took in May 1995, cynically doubting the ability of the TRC to deal with its assignment in a fair and evenhanded manner. The matters of amnesty and restitution after the TRC hearings and reports remained in issue for another two to three years. In 2001, after a long silence, the TRC is topicalised on the front page of Die Kerkbode once again. This time the frontpage headline is an imperative: "Gee nóu amnestie" (Give amnesty nów), and the heading of the lead is an exhortation: "Ja vir die soort algemene amnestie" (Yes to thís kind of general amnestie). The new president, $\mathrm{Mr}$ Thabo Mbeki, is advised in the interest of reconciliation, to declare general amnesty to all who grossly violated human rights during the years of the struggle, regardless of their political affiliation.

\subsubsection{Excerpts from the discourses as indicators of attitude}

Taking a closer look at the content of the frontpage reports and the lead articles, an interesting process of taking position, moving the position and then returning to the first position, becomes clear.

In May 1995, before the TRC had been properly set up, Die Kerkbode topicalised the anticipated commission as one that had little hope of achieving its goals. Excerpt 1 illustrates how concerns about an ideological stance are articulated. DRC concerns about the possibility that the process will contribute to spiralling violence with limited benefits 
for the whole South African community, are expressed. Particularly, there is focus on how the DRC will take initiative in responding to what is decided and to what transpires. The attitude is one that lacks confidence in the peace process for which the recently passed legislation made provision. The church would monitor, and ministers were urged to give pastoral care to participants. This is a fairly direct vote of no confidence in the envisaged TRC route to reconciliation: there is a possibility that it will not satisfy the requirements set by a "Christian conscience". The church will assume a watchdog role. There is an irony here, as a similar pronounced watchdog position was much less in evidence during the 1980 s when rumours of serious atrocities of members of the security forces abounded. ${ }^{13}$ Reference to "the whole South African community" carries the implication that not all are suitably prepared for what lies ahead; most probably the concern here is for the DRC's own membership.

Excerpt 1

"Die Waarheidskommissie, wat binnekort aangestel word, is by voorbaat deur die Ned Geref Kerk versoek om toe te sien dat die proses waarby hy betrokke sal wees, onpartydig sal geskied en nie 'deur 'n ideologiese vertrekpunt' bepaal sal word nie. Dit is ook baie belangrik dat 'die hele Suid-Afrikaanse gemeenskap behoorlik voorberei' word op die werk van die Waarheidskommissie. ... die NG Kerk (beoog) om die verloop van die proses te monitor vir prosedures wat nie die toets van die Christelike gewete kan deurstaan nie. Die Dagbestuur van die ASK doen ook 'n ernstige beroep op kerkrade en leraars om moontlike verontregtes en beskuldigdes wat by die proses betrek word, pastoraal te begelei" (Die Kerkbode, 26 May 1995, p.1).

["The Truth Commission that will be appointed soon, has been requested in advance by the DRC to take care that the process in which it will be involved, will be impartial and will not be determined by an "ideological point of departure". It is also very important that the whole of the South African community be properly prepared for the work of the Truth Commission. ... The DRC plans to monitor the process in order to detect procedures that cannot endure the test of the Christian conscience. The executive of the ASK urgently calls on church councils and ministers to give pastoral care to those who may be aggrieved or accused in the TRC processes."']

In October 1995 the attitude is similarly sceptical. Excerpt 2 illustrates an attitude of greater concern for general crime levels after 1994 than for the particular political violence of the years before, that would be investigated by the TRC. That political and structural violence during the years of apartheid and the struggle against, in a certain sense laid the foundations for the violent behaviour of many in the aftermath, is not considered. Concern that the process will not be impartial, is reiterated.

Excerpt 2

"Mnr Omar hoop dat ... die Waarheidskommissie daartoe sal bydrae dat 'n 'nuwe moraliteit' in die land sal posvat. Daar moet nou 'n einde kom aan al die brutaliteit, geweld en misdaad wat teenoor mense gepleeg word ..." (Die Kerkbode, 6 October 1995, p.1).

13. For a discussion of attention in Die Kerkbode to indications of State violence during the States of Emergency 1985 - 1990, see Anthonissen (2001: 26-29). 
["Mr Omar hopes that the Truth Commission will contribute to a 'new morality' taking root in the country. There has to come an end now to all the brutality, violence and crime committed against people ..."]

A second lead article of November 1995 still has a sub-text that articulates doubt as to the integrity, impartiality or honesty of the envisaged process. Excerpt 3 expresses concerns that the TRC process will degenerate into a witchhunt. It dwells on how difficult it is to capture any authentic "truth".

Excerpt 3

“... as opdrag 'n baie moeilike en hoogs omstrede werk: om vas te stel wat die 'waarheid' in die Suid-Afrikaanse verlede van die afgelope paar dekades is, en om nie in die lig daarvan 'n heksejag van die een of ander aard op tou te sit nie, maar versoening in ons verskeurde samelewing te bewerkstellig... Die 'waarheid' ... is nie die alleenbesit van 'n bepaalde groep of hulle simpatiseerders nie. Daar sal met integriteit, onpartydigheid en eerlikheid na die waarheid gesoek moet word ..." (Die Kerkbode, 17 November 1995, p.4).

["The assignment (of the TRC) is very difficult and highly controversial: to determine the 'truth' of the past few decades of South African history, and in view of that not to start out on some sort of witch hunt, but to bring reconciliation in our torn society ... The 'truth' is not the sole property of a particular group or its sympathisers. The truth will have to be sought with integrity, impartiality and honesty ..."]

Early in 1996 a group of 46 ministers brought together by Rev Martin Heyns of Pinelands, Cape Town, submitted a letter to Die Kerkbode (9/10 February 1996, p.7), imploring the publication to assist the DRC and its members not to undermine the task of the TRC by doubting and stigmatising its intentions and actions. Rather, they want the church to become constructively involved in the TRC processes. Excerpt 4 gives the gist of an editorial response which first commends the appointment of Prof Piet Meiring, a theologian at the DRC seminary in Pretoria, as a commissioner of the TRC, and then supports the plea of the 46 . The strength of such support is mitigated in that readers are reminded that Prof Meiring is not a member of the TRC as an official representative of the DRC, that the DRC will not as a result of his membership condone every decision the commission takes, and that the DRC still needs to maintain a critical distance. Nevertheless, this edition marks a subtle change in tone that became gradually more pronounced. The question of how to become "constructively involved" is a move away from "monitoring" and checking procedures that may offend the Christian conscience.

\section{Excerpt 4}

"Ons stem saam dat die kerk inderdaad betrokke moet raak en weë moet vind om 'n opbouende rol ten opsigte van die Waarheidskommissie te speel. Dit beteken sekerlik, soos die briefskrywers sê, dat ook van kerklike kant gewaak moet word teen 'n verdagmakery van die kommissie. Maar dit beteken óók wel dat die kerk moet waarsku teen 'n eensydige beoordeling deur die kommissarisse van ons geskiedenis die afgelope jare deur die oorbeklemtoning van apartheidsondes en die onderbeklemtoning van antiapartheidsondes - of andersom" (Die Kerkbode, 9/10 February 1996, p.6).

["We agree that the church should indeed become involved and should seek ways to play a constructive role in relation to the Truth Commission. This certainly means, as the correspondents note, that the church should guard against casting suspicion on the commission. But that also means that the church has to warn against one-sidedness when 
the commissioners judge on our history of the past couple of years by over-emphasising the sins of apartheid and under-emphasising the sins of anti-apartheid - or vice versa.']

By March 1996, after the first public hearings of Human Rights Violations, the tone is considerably less assured in foregrounding the weaknesses the DRC detected in the national process. After discussions between the Moderature of the General Synod and Archbishop Tutu, the best intentions of the TRC appear to be accepted. Excerpt 5 is from an editorial that cautioned readers that the process was bound to be traumatic and to last for quite a while - up to two years. There is recognition that certain atrocities now brought to light, were undoubtedly offensive and delictual. Even so, the regular reminder that finding a balance is no mean task and that great care has to be taken by the ANC-loaded commission, is included in a manner characteristic to all the editorials.

Excerpt 5

"Die kommissie se bedoeling ... is om versoening en genesing ... te bring, nie om 'n heksejag op tou te sit nie. ... Die kommissie wil reg en geregtigheid laat geskied, wil billik en onbevooroordeeld sy werk doen ... Die opdiep deur die kommissie van die dinge van ons onlangse verlede gaan 'n tyd lank duur ... dan gaan die kommissie sy boeke toemaak en die verlede verder met rus laat. ... Dit sal vir ons almal 'n traumatiese tyd wees ... kan ook 'n tyd van suiwering wees, 'n katarsis wat vir ons verskeurde samelewing uiteindelik heling kan bring" (Die Kerkbode, 1 Maart 1996, p.6).

["The intention of the commission is to bring about reconciliation and healing, not to start out on a witch hunt. The commission wants justice and righteousness, wants to do its work in fairness and without prejudice ... The commission's digging up of things of our recent past will last a while yet ... then the commission will close its books and let the past rest. It is going to be a traumatic time for all of us ... it can also be a time of purging, a catharsis that can eventually bring healing to our torn society."]

Two months later, more hearings had brought to the fore harrowing histories that shamed many who previously had not believed the TRC would produce more than fabricated stories and emotional re-inventions or exaggerations. Then another editorial topicalised the TRC process. Excerpt 6 talks about the shock and pain of being confronted with violations related either for the first time, or in detail that was not formerly accessible. Even if one conceded that evidence was often technically "untested", the truth of much and the horrors that countless ordinary people had lived through, could no longer be denied. Here, for the first time the tone reminds of an apology: "niemand ... kan goed daaroor voel nie". "Where was the prophetic voice of the Afrikaans churches at the time?" English churches that did speak out, are commended (with the regular mitigating remark that it was sometimes too over-the-top and could thus not be "heard"). There is also reference to voices from the Afrikaans churches that protested, but had been ignored. In this lead article there is a direct appeal to the church and its members to start doing things differently, to acknowledge responsibility for the shameful and embarrassing events the TRC had started to disclose.

Excerpt 6

"(Dit is) 'n traumatiese ervaring om daagliks op televisie gekonfronteer te word met 'beelde van die verlede' ... Ja, party van hulle onthou seker verkeerd ... dis hoofsaaklik ongetoetste getuienis ... Maar hoe ookal: baie van wat getuig word, is sekerlik die waarheid. En niemand wat dit sien en hoor kan goed daaroor voel nie ... Wáár was diegene onder ons wat moes gepraat en gekeer het? Wáár was, by name, die Afrikaanse 
kerke toe hulle 'n protesstem en 'n profetiese stem moes laat hoor het?"'(Die Kerkbode, 3 May 1996, p.6).

["It is a traumatic experience to be confronted on a daily basis with 'images of the past' on television... Indeed, some of (the witnesses) may have faulty memories ... it is largely untested evidence ... But whichever way you look at it: much of what is given in testimony, is certainly the truth. And nobody who sees and hears it can feel good about it ... Where were those among us that should have spoken out and prevented what had happened? Where were, specifically, the Afrikaans churches when they should have spoken clearly in a voice of protest and with a prophetic voice?"]

During 1997 Die Kerkbode took the position that there should be a formal and official submission of the ASK, the elected church leadership, to the TRC. However, this was not to be. Growing dissatisfaction and disenchantment in some regions prompted a fairly defensive second lead article in December 1997, where the actions that the church had taken were listed and explained to quell rumours, reproaches and slurs coming from conservative parts of the constituency.

And then early in 1998 another shift becomes apparent. The mood of atonement so unequivocally expressed in 1996, changed. After an interview with Archbishop Tutu concern is expressed in anticipation of the publication of the final report of the TRC. A summary of what became clear during the interview, once again bears the tone of doubt and suspicion. After referring to the bad relationship between Dr Tutu and former president PW Botha who refused to testify before the TRC, both Tutu and Botha are rather patronizingly reprimanded, as excerpt 7 illustrates. Then, in the closing paragraph Dr Tutu is directly addressed in a tone that is more a challenge to his promises than a sincere expression of trust in the assurances he had given. This is virtually a return to the position of scepticism evident at the outset in 1995.

Excerpt 7

"Die oor en weer skellery wat nou plaasvind, doen in elk geval nie een van hulle eer aan nie. En bevorder versoening op geen manier nie. ... Goed, dr Tutu. Ons neem u op u woord: die verslag van die WVK gaan billik en regverdig wees. Dit gaan brûe bou, nie afbreek nie. Dit gaan nie doekies om die waarheid draai nie, maar versoening in ons land ook daadwerklik bevorder. Mag die Here u help om u woord gestand te doen" (Die Kerkbode, 6 Maart 1998, p.6).

["The mutual slinging of abuse that is taking place now, does not serve any of them well. And neither does it benefit reconciliation in any way. OK, Dr Tutu. We'll take your word for it: the TRC report will be fair and just. It will build bridges, not destruct them. It will not mince matters, but will actually promote reconciliation in our country. May the Lord help you to honour your word."]

Overall, there are three things to be remarked about the particular style of the lead articles that exhibit three kinds of ambiguity. First, the articles are characterised by generalisations that avoid naming people or specific instances. For example, in excerpt 1 , when the concern about an "ideological point of departure" is expressed, no details are given as to which ideology may be meant, who would take such a position or what the practical implications would be of such a point of departure. There is an assumption of unspoken understanding between producers and receivers of the text. This is a typical strategy used in constructing consensus, and thus discouraging healthy debate. ${ }^{14}$ Again, in

14. For a discussion of constructing consensus through conversationalisation and marketisation strategies, see Anthonissen (2001: 22-27). See also Fowler (1991). 
excerpt 2, there is reference to "brutality, violence and crime" - clichéd terms are used without specific contextualisation. No specification is given of what particular brutalities are meant and how were these relate to the brutalities of the past that the TRC was set up to investigate. Such vagueness in reference is so prevalent as to allow an interpretation of deliberate choice for ambiguity: for those who cannot confront the reading that refers to a violent past in which the readers may be identified with the perpetrators, there is the possibility of a reading that refers to current crimes in which the readers may be identified with the victims.

Second, the majority of the lead articles are characterized by a kind of reluctance to take a principled position and defend it unambiguously. For example, in excerpt 5 there is clear agreement with expressed intentions of the TRC as they were represented by Archbishop Tutu. However, halfway through the argument there is a complaint that what some felt was a just war, others found to be unwarranted acts of terror. There is also a complaint that some perpetrators of violence would be exposed by the TRC while others had prematurely been given amnesty. And there is a complaint that previously warring groups were not equally represented in the Truth Commission. This creates the impression that the writer is ambiguous about the position the church should take. It has the effect of undermining the "constructive engagement" position, and of bringing doubt as to the sincerity of the earlier expressed support for the intentions of the TRC and for the process as a public means to "bridging past and future" and "pursuing unity and well-being".

Third, the lead articles are characterised by sermon-like conclusions. On the one hand the TRC's pursuit of reconciliation is addressed as a secular, political process and arguments are presented in a rhetorical style typical of public debate. Such a style is in stark contrast with that of conclusions such as "And those who confess, confess in the right way before God and neighbour, receive forgiveness in the Name of Jesus Christ. Seventy $x$ seven times" (Die Kerkbode, 3 May 1996, p.6), or as in excerpt 7 "May the Lord help you to honour your word." There is a marked ambiguity in that the functions of these different styles do not complement one another: a reader who initially feels invited to question or contest a position taken up in the earlier argument, is silenced by the structure of the conclusion. The opportunity for engaging in what is clearly a debate inside of the church and outside, is one-sidely closed down.

\section{Conclusion}

In summary, it appears that the reports on the TRC in Die Kerkbode at first showed minimal appreciation for the intentions of the TRC, and expressed doubt about the reliability or integrity of the process. As the hearings got underway there was a marked change. However, the reports never went beyond a very narrow interest in the responses of the official church, the position of the DRC in negotiating conditions for national reconciliation and the possible perceptions of DRC members.

References to Archbishop Tutu as the chairperson of the TRC were ambiguous, as were many other references to the TRC processes. Towards the end, from 1998 to 2002, much of the earlier judgemental and self-interested style returns. The texts aim at avoiding confrontation with dissenting members in the DRC; they are aimed more at pacifying members critical of the process. Otherwise they have the function of defending the position of the DRC as an institution. The function of bringing readers to new insights, of persuading them to engage constructively, is limitedly fulfilled. Eventually questions about amnesty are posed, but there are no questions about restitution. 
Particularly notable is not only what was topicalised and discussed, but also what was neglected and thus kept from consideration in DRC discourses. The power of narrative and its persuasive effect was never utilised. This is remarkable, as it is otherwise a regularly invoked discursive style in religious discourses. To illustrate the effect of the absence of narrative in Die Kerkbode, I shall relate a personal experience. I attended the TRC hearings in Paarl on the day that the Stellenbosch presbytery brought its submission. ${ }^{15}$ I arrived there along with a handful of DRC members when proceedings started at 09:00 am. That morning we witnessed not only the stories, but actually heard the voices, saw the faces, briefly glimpsed into the world of ordinary people whose experiences never came to the attention of the majority of DRC members during the 1980s. They did not receive media coverage. Watching and hearing this was humbling and harrowing to say the least. The stories of that morning have remained with me longer and more vividly than many much publicized ones. I shall mention only three. There was the story of a young man, $\mathrm{Mr}$ Ndinisa, who as a 16-year old was supposed to be educated and become the breadwinner of his family, but was carelessly shot and hit in the spine during a police raid. He still lives with the effects of that event:

"What I noticed and what I heard from people is that I am short tempered, I quarrel a lot with people and that makes me unhappy. I become temperamental and thereafter I regret but my mother has been told that I'm being affected by the bullets. But as for now I - I can't stand for a long time because I - if I stand for long time I have some pains on my back."16

There was also a story of a man who had been a leader in the UDF in the black township near Paarl, who was arrested for his political leadership:

"Randindi was also there in the very same room, he started beating me up again with the other policemen. There was nobody who was telling him to stop, even Swanepoel himself was also beating me. While they were still assaulting me Swanepoel said that this is your day today. And we've been hearing a lot about you, that you are necklacing people. Today we are going to necklace you - this is your day today, we are going to kill you. That's what Mr Swanepoel said to me, I kept quiet just looking at them. One of the policemen came in with a box, they placed this box in this room. They opened this box. Mr Swanepoel said I must take off my clothes - all of my clothes, I should be naked. I tried to - to struggle but I didn't have enough strength - I was assaulted again by Randindi and Swanepoel. I took off my clothes and I remained naked. They put me in this - they took out a snake from this - from this box. They wrapped this snake around my body - I was naked. They - they wrapped - they - the snake fell and they took it back again and they wrapped it around my neck. I was still naked all the time, the snake fell again ..."17

And there was the story of a woman who had lost her husband, a community leader and UDF supporter. He had been brutally stabbed under suspect circumstances:

"That was on the $29^{\text {th }}$ when they came to inform me. He's been murdered, I did not know what was happening. I did not know of anybody that bore any grudges against him. I just don’t know.

15. Die Kerkbode reported on this in its edition of 18 October 1996.

16. Text taken from recordings transcribed on the TRC website http://www.doj.gov.za/trc/hrvtrans/Wineland/ct00259.htm

17. Text taken from recordings transcribed on the TRC website: http://www.doj.gov.za/trc/hrvtrans/Wineland/ct00260.htm 
But what raised doubts in my mind and what raised questions which brought me here is that in the first place I wasn't allowed to go and identify my husband's body. The police simply did not want me to and since the evening of the $29^{\text {th }}$ they started watching my house. We were not aware of that because initially there were a lot of people and a boy - my sister's son who I had raised was residing in Wellington. When he was on his way home that evening, he came back to tell us the people - to tell the people to come and look because the police were watching the house.

And when the people went out to go and look the police drove off. My question is why did they watch the house and if they were worried about me and my condition why did they not come to me and say madam we are worried about you, that is why we are watching your house." $" 18$

What struck me on that day was that the DRC delegation who read the submission of the Ring van Stellenbosch, arrived during the lunch break and had their turn to speak directly as proceedings started again. They left immediately after. They had not heard any of the stories that had set the background to their submission that day. Listening to the submission, and reading it afterwards, it was difficult to relate its content to what had been presented the morning before or the day after. This illustrates to me an element of what was lacking in so many of the DRC discourses, also those in Die Kerkbode. The leadership was busy with its own status in the public domain. It was concerned about stating its own views and defending its own position. It did not get close to the stories of brutality and abuse that were supposed to be in focus, that somehow could have become vehicles to better understanding and thus to reconciliation.

Finally, after studying editions of Die Kerkbode from 1995 to 2002 to determine what kind of impression the TRC made on the Dutch Reformed Church, what kind of responses the church found appropriate, I am left with two questions:

1. What must we make of the fact that the DRC found it so difficult to talk about the TRC in other than predominantly defensive terms, that refer largely to their own visibility in the TRC process?

2. When the church did report on the TRC, why was it so difficult to respond with compassion to the pain and incredible sadness that was so evident in the narratives of thousands of people who obviously had had very little power to defend themselves and their loved ones?

18. Text taken from recordings transcribed on the TRC website: http://www.doj.gov.za/trc/hrvtrans/Wineland/ct00433.htm 


\section{BIBLIOGRAPHY}

Anthonissen, C 2001. "Critical discourse analysis: A methodological discussion for analysis of editorials on the state of emergency, Die Kerkbode 1986 - 1989". In Scriptura 76 (2001:1): 17-31.

Anthonissen, C 2002. "Interaction between Visual and Verbal Communication: Changing patterns in the Printed Media”. In Weiss, G \& Wodak, R. Critical Discourse Analysis: Theory and Interdisciplinarity, pp. $297-311$.

Boraine, A 2000. A Country Unmasked - inside South Africa's Truth and Reconciliation Commission. London, Cape Town: Oxford University Press.

Chouliaraki, L 1999. "Media Discourse and National Identity: Death and Myth in a News Broadcast.” In Wodak, R \& Ludwig, C. Challenges in a Changing World: issues in Critical Discourse Analysis. Vienna: Passagen Verlag. Pp. 37-62.

Codrington, G 1997. "A Discussion of the Truth and Reconciliation Commission in South Africa, in the light of Christian Evangelical Theology". Online at http://www.youth.co.za/papers/trc.htm.

Fairclough, Norman 1989. Language and Power. London, New York: Longman.

Fowler, Roger 1991. Language in the News. London, New York: Routledge.

James, WM, Van de Vijver, L \& Van de Vijver, K (eds.) 2001. After the TRC: Reflections on Truth and Reconciliation in South Africa. Chicago: Ohio University Press.

Krog, A 1998. Country of my Skull. Johannesburg: Random House.

Matouschek, B, Wodak, R \& Januschek, F 1995. Notwendige Massnahmen gegen Fremde? (Necessary regulations against foreigners?). Vienna: Passagen Verlag.

Muntigl, P, Weiss, G, Wodak, R 2000. European Union Discourses on Un/employment. Amsterdam: John Benjamins.

Rotberg, RI \& Thompson, D 2000. Truth v. Justice: the morality of Truth Commissions. Princeton, NJ: Princeton University Press.

Reisigl, M, Wodak, R ???. Discourse and Discrimination. London, New York: Routledge.

Scollon, Ron 1998. Mediated discourse as Social Interaction. London, New York: Longman.

Scollon, Ron 1999. "Official and Unofficial Discourses of National Identity: Questions Raised by the Case of Contemporary Hong Kong”. In Wodak, R \& Ludwig, C. Challenges in a Changing World: issues in Critical Discourse Analysis. Vienna: Passagen Verlag. Pp. 21-35.

Titscher, S, Wodak, R, Meyer, M \& Vetter, E. 1998. Methoden der Textanalyse. Opladen/Wiesbaden: Westdeutscher Verlag.

Tutu, DM 2000. No Future without Forgiveness. New York: Doubleday/Randomhouse.

Verwoerd, WJ 1999. "Individual and/or Social Justice After Apartheid? The South African Truth and Reconciliation Commission", The European Journal of Development Research 1999; 11(2): 115-140.

Weiss, G \& Wodak, R 2002. Critical Discourse Analysis: Theory and Interdisciplinarity. London, Amsterdam: Palgrave Macmillan.

Wodak, R \& Ludwig, C (eds.) 1999. Challenges in a Changing World: issues in Critical Discourse Analysis. Vienna: Passagen Verlag.

Wodak, Ruth \& Meyer, Michael. 2001. Methods of Critical Discourse Analysis. London: Sage. 
Editions of Die Kerkbode specifically referred to:

26 May 1995 ,

6 October 1995 ,

17 November 1995 ,

9/10 February 1996,

1 March 1996,

3 May 1996,

6 September 1996,

18 October 1996 ,

7 November 1997.

5 December 1997

6 March 1998

November/December 2001

\section{Websites:}

http://www.ijr.org.za http://www.doj.gov.za/trc/

http://www.doj.gov.za/trc/legal/act9534.htm

http://www.doj.gov.za/trc/hrvtrans/Wineland/ct00259.htm

http://www.doj.gov.za/trc/hrvtrans/Wineland/ct00260.htm

http://www.doj.gov.za/trc/hrvtrans/Wineland/ct00433.htm 